\title{
Unaffected Electrogenic Na-K Pump Activity in \\ "Diseased" Human Atrial Fibers, as Assessed by Intracellular $\mathrm{K}^{+}$Activity
}

\author{
Hidenori Sako, Sunao Imanishi,* Makoto Arita, \\ Tatsuo Shimada, ${ }^{* *}$ Tetsuo Hadama, ${ }^{* *}$ and Yuzo UCHidA ${ }^{* * *}$ \\ Department of Physiology, ${ }^{* *}$ Department of Anatomy, \\ and ${ }^{* * *}$ Department of Surgery, Faculty of Medicine, \\ Medical College of Oita, Hazama-cho, Oita, 879-56 Japan
}

\begin{abstract}
To investigate the role of the electrogenic $\mathrm{Na}-\mathrm{K}$ pump in the resting membrane of "diseased" or "depolarized" human atrial muscles, intracellular $\mathrm{K}^{+}$activity $\left(a_{\mathrm{K}}^{\mathrm{i}}\right)$ and resting membrane potential $\left(V_{\mathrm{m}}\right)$ were simultaneously measured using double-barreled $\mathrm{K}^{+}$-selective microelectrodes. Under perfusion with normal Tyrode's solution $\left(37^{\circ} \mathrm{C}\right)$ containing $5.4 \mathrm{~mm}[\mathrm{~K}]_{0}, \quad V_{\mathrm{m}}$ averaged $-43.9 \pm 1.4 \mathrm{mV}$, and $a_{\mathrm{K}}^{\mathrm{i}}$ was $99.7 \pm 1.3 \mathrm{~mm}$ (mean \pm S.E., $n=33$ ). The $a_{\mathrm{K}}^{\mathrm{i}}$ was comparable to that of atrial muscles obtained from other intact mammalian species. In $5.4 \mathrm{mM}[\mathrm{K}]_{\mathrm{o}}$, dihydro-ouabain (DHO) at concentrations of $10^{-6}$ and $10^{-5} \mathrm{M}$ significantly decreased $a_{\mathrm{K}}^{\mathrm{i}}$ and depolarized $V_{\mathrm{m}}$. Similar decreases in $a_{\mathrm{K}}^{\mathrm{i}}$ were observed when $[\mathrm{K}]_{\mathrm{o}}$ was decreased from 5.4 to $0.5 \mathrm{~mm}$ or when the temperature of the perfusing solution was decreased from 37 to $22^{\circ} \mathrm{C}$. Upon returning $[\mathrm{K}]_{\mathrm{o}}$ from 0.5 to $5.4 \mathrm{mM}$ at $37^{\circ} \mathrm{C}, a_{\mathrm{K}}^{\mathrm{i}}$ increased, $V_{\mathrm{m}}$ hyperpolarized markedly for about $3 \mathrm{~min}$, and this was followed by less marked levels of hyperpolarization in the steady state. The high $[\mathrm{K}]_{\mathrm{o}}$-induced increases in $a_{\mathrm{K}}^{\mathrm{i}}$ were inhibited in the presence of DHO, and at low temperature $\left(22^{\circ} \mathrm{C}\right)$. Isoproterenol $\left(10^{-7} \mathrm{M}\right)$ increased $a_{\mathrm{K}}^{\mathrm{i}}$ and hyperpolarized $V_{\mathrm{m}}$. Acetylcholine $\left(10^{-5} \mathrm{M}\right)$ hyperpolarized $V_{\mathrm{m}}$ with no change in $a_{\mathrm{K}}^{\mathrm{i}}$. The rate of reduction of $\mathrm{Na}^{+}$-efflux during application of DHO $\left(10^{-5} \mathrm{M}\right)$ was calculated based on the change in $a_{\mathrm{K}}^{\mathrm{i}}$ and surface-to-volume ratio of the cell measured electronmicroscopically in the same tissue, and estimated to be 2.6 to $3.8 \mathrm{pmol} /\left(\mathrm{cm}^{2} \cdot \mathrm{s}\right)$, close to the value reported for Purkinje fibers excised from intact animals. We conclude that the Na-K pump functions normally even in "diseased" human atrial muscles, thereby keeping $a_{\mathrm{K}}^{\mathrm{i}}$ within a physiological range.
\end{abstract}

Key words: human atrial fiber, $\mathrm{K}^{+}$-selective microelectrode, electrogenic $\mathrm{Na}-\mathrm{K}$ pump, dihydro-ouabain, low temperature.

* To whom all correspondence should be addressed. 
The Na-K pump operates against the electrochemical gradient of $\mathrm{Na}^{+}$and $\mathrm{K}^{+}$to maintain intracellular $\mathrm{Na}^{+}$and $\mathrm{K}^{+}$concentration homeostasis. The pump extrudes $\mathrm{Na}^{+}$from the cell to a greater degree than it takes up $\mathrm{K}^{+}$and thus generates a net outward current (electrogenic $\mathrm{Na}^{+}$pump current). This pump current, in conjunction with the ionic gradient and ionic membrane conductance, affects the membrane potential (GLITSCH, 1979).

Diseased human atrial fibers are characterized by low, non-uniform levels of the resting membrane potential (TEN EICK and Singer, 1979; MARY-RABINE $e t$ al., 1983; IMANISHI and ARITA, 1987). Such changes have been attributed to non-homogeneous decreases in the resting $\mathrm{K}^{+}$conductance (TEN EICk and SiNGER, 1979), increases in the resting $\mathrm{Na}^{+}$conductance (IMANISHI and ARITA, 1987), and impairment of the electrogenic Na-K pump (LEE, 1986). However, IMANISHI and ARITA (1987) emphasized the role of electrogenic Na-K pump current in maintaining the resting potential at relatively high levels, which counteracted the depolarization due to the altered ionic membrane conductance. However, their conclusion was derived from alterations of the membrane potential measured before and after inhibition of the Na-K pump by various procedures such as ouabain or low external $\mathrm{K}^{+}$concentration, which inevitably affects the membrane conductance. To evade this problem and clarify the functional role of the Na-K pump in diseased human atrial preparations, we attempted to measure the intracellular $\mathrm{K}^{+}$activity, $a_{\mathrm{K}}^{\mathrm{i}}$ as a quantitative index of $\mathrm{Na}-\mathrm{K}$ pump activity, by using double-barreled $\mathrm{K}^{+}$-selective microelectrodes. The main purposes of the study are to determine: 1) whether or not the Na-K pump activity is impaired in depolarized or diseased human atrial preparations; and 2) the functional effect of the $\mathrm{Na}-\mathrm{K}$ pump current on the resting potential of those preparations.

\section{MATERIALS AND METHODS}

Preparations and procedures. Specimens of right atrial appendage were obtained from 33 patients undergoing corrective cardiac surgery for various congenital and acquired heart diseases. The patients were selected consecutively in order of the operation and ranged in age from 3 to 72 years (Table 1). No patient had been treated with digitalis or antiarrhythmic agents within 2 months prior to surgery. Their electrocardiogram revealed no atrial fibrillation and examination of cardiac catheterization disclosed the mean right atrial pressure to be less than $8 \mathrm{mmHg}$.

As a part of the routine atriotomy in open heart surgery, a small specimen was removed from the appendage of the right atrium. Immediately after excision, the tissue was immersed in cold oxygenated Tyrode's solution $\left(5-6^{\circ} \mathrm{C}\right)$ and taken to the laboratory. A few trabeculae, $0.8-1.5 \mathrm{~mm}$ long and $0.3-0.8 \mathrm{~mm}$ wide, were dissected from the specimen under a dissecting microscope. The preparation was mounted in a Lucite chamber $(0.8 \mathrm{ml})$ and superfused (flow rate, $3-4 \mathrm{ml} / \mathrm{min}$ ) with warmed $\left(37 \pm 0.2^{\circ} \mathrm{C}\right)$ Tyrode's solution. Specimens were allowed to equilibrate in 
Table 1. Number of patients classified by clinical diagnoses.

Congenital heart disease

Atrial septal defect

Ventricular septal defect

Acquired heart disease

Valvular disease

Coronary artery disease

Unspecified
16

10

6

9

7

1

Tyrode's solution for $1 \mathrm{~h}$ prior to study. To measure $a_{\mathrm{K}}^{\mathrm{i}}$, multiple impalements were made on the surface of the preparation with a double-barreled $\mathrm{K}^{+}$-selective microelectrode. Only stable records lasting for more than $5 \mathrm{~min}$ were used as data. When the impalement was successful for more than 20-30 min, various test solutions were introduced into the chamber to alter the Na-K pump activity and to check changes in $a_{\mathrm{K}}^{\mathrm{i}}$. The procedure included change of external $\mathrm{K}^{+}$concentration $\left([\mathrm{K}]_{\mathrm{o}}\right)$, change of the temperature of the perfusing solution, and application of dihydro-ouabain, isoproterenol, or acetylcholine.

Solutions. The control Tyrode's solution contained (in $\mathrm{mm}$ ): $\mathrm{NaCl}, 136.7$; $\mathrm{KCl}, 5.4 ; \mathrm{CaCl}_{2}, 1.8 ; \mathrm{MgCl}_{2}, 0.5 ; \mathrm{NaHCO}_{3}, 11.9 ; \mathrm{NaH}_{2} \mathrm{PO}_{4}, 0.42 ;$ glucose, 5.0. Solutions with $0.5 \mathrm{~mm} \mathrm{~K}{ }^{+}$were made by equimolar substitution of $\mathrm{Na}^{+}$for $\mathrm{K}^{+}$. In some experiments, dihydro-ouabain (DHO), isoproterenol (Iso), or acetylcholine (ACh), were added directly to the Tyrode's solution to give final concentrations of $10^{-6}-10^{-5}, 10^{-7}$, and $10^{-5} \mathrm{M}$, respectively. All solutions were equilibrated with $97 \% \mathrm{O}_{2}-3 \% \mathrm{CO}_{2}$, making the $\mathrm{pH} 7.35$ to 7.40 , and kept at $37 \pm 0.2^{\circ} \mathrm{C}$. For cooling experiments, cold Tyrode's solution $\left(22^{\circ} \mathrm{C}\right)$ was introduced into the perfusion chamber. The temperature of the bath solutions could be changed from 37 to 22 , or 22 to $37^{\circ} \mathrm{C}$ within $3 \mathrm{~min}$ by passing the Tyrode's solution through coiled polyethylene tube immersed in chilled water.

Fabrication of $\mathrm{K}^{+}$-selective microelectrodes. The method of preparing $\mathrm{K}^{+}$-selective microelectrodes (KISEs) was essentially the same as that described by HотоKEBUCHI et al. (1987). In brief, two capillaries (Narishige, GD-1) were mounted in parallel on a horizontal micropipette puller (Narishige, PW-77), and heat was applied. The capillaries were then twisted $180^{\circ}$ and pulled. The tip diameter of these capillaries was smaller than $0.5 \mu \mathrm{m}$. After one barrel was siliconized, it was back-filled with potassium ionophore (Fluka, 60031), until the ionophore column became approximately $100 \mu \mathrm{m}$ in length from the tip to the base. The remaining portion of this barrel was filled with $0.5 \mathrm{M} \mathrm{KCl}$. The other barrel (reference) was back-filled with $1 \mathrm{M} \mathrm{NaCl}$. The DC-resistance of the $\mathrm{K}^{+}$-selective barrel and the reference barrel were 10-100 G $\Omega$ and 20-60 M $\Omega$, respectively. The KISE, thus prepared, was stable for more than $12 \mathrm{~h}$. The "response time" (НотокEвUCHI et al., 1987) of the 
A

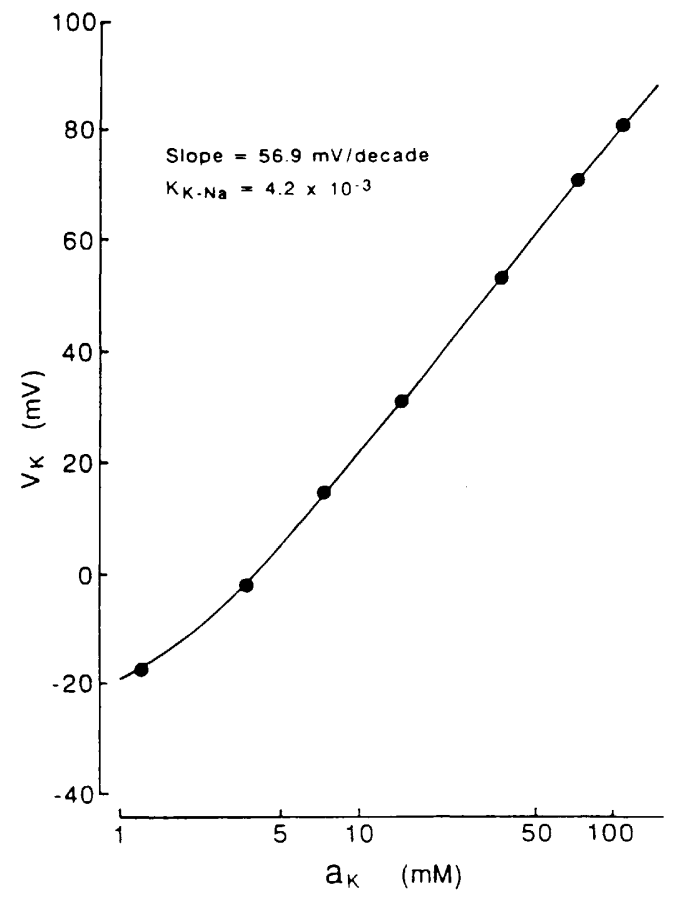

B
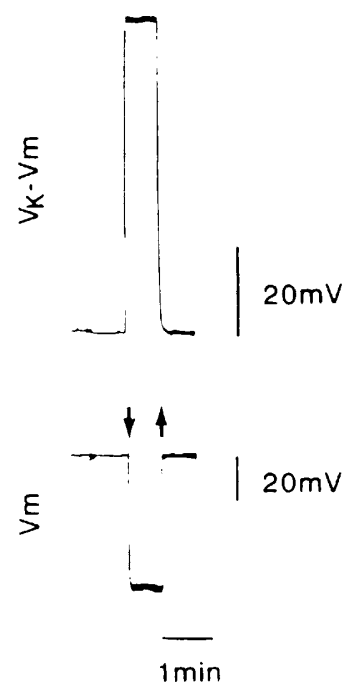

Fig. 1. A: calibration curve for a double-barreled $\mathrm{K}^{+}$-selective microelectrode. $V_{\mathrm{K}}$, potential measured by the $\mathrm{K}^{+}$-selective electrode; $a_{\mathrm{K}}$, activity of K-ion. $V_{\mathrm{K}}$ (ordinate) is plotted against the logarithm of $a_{\mathbf{K}}$ (abscissa) in solutions containing various combinations of concentrations of $\mathrm{K}^{+}$and $\mathrm{Na}^{+}$(see METHODS). B: an example of the measurement of intracellular $\mathrm{K}^{+}$activity $\left(a_{\mathrm{K}}^{\mathrm{i}}\right)$. Bottom trace, membrane potential from reference barrel $\left(V_{\mathrm{m}}\right)$; top trace, potential difference between the $\mathrm{K}^{+}$-selective barrel and reference barrel reflecting $a_{\mathrm{K}}^{\mathrm{i}}\left(V_{\mathrm{K}}-V_{\mathrm{m}}\right)$. Downward arrow, cellimpalement; upward arrow, withdrawal of electrode.

KISE was measured to be in less than $10 \mathrm{~s}(\tau=4 \mathrm{~s})$. The $a_{\mathrm{K}}^{\mathrm{i}}$ was measured only at resting condition of the preparation, because of its slow response time. If spontaneous activity was induced in low $[\mathrm{K}]_{\mathrm{o}}$ or in the presence of $\mathrm{DHO}, a_{\mathrm{K}}^{\mathrm{i}}$ was measured after cessation of the spontaneous activity.

Calibration. All KISEs were calibrated before and after each experiment in solutions consisting of mixtures of $\mathrm{KCl}$ and $\mathrm{NaCl}$ with the total concentration fixed at $150 \mathrm{~mm}(5 \mathrm{~mm} \mathrm{KCl}+145 \mathrm{~mm} \mathrm{NaCl} ; 10 \mathrm{~mm} \mathrm{KCl}+140 \mathrm{~mm} \mathrm{NaCl} ; 20 \mathrm{~mm} \mathrm{KCl}$ $+130 \mathrm{mM} \mathrm{NaCl} ; 50 \mathrm{~mm} \mathrm{KCl}+100 \mathrm{~mm} \mathrm{NaCl} ; 100 \mathrm{mM} \mathrm{KCl}+50 \mathrm{mM} \mathrm{NaCl}$; and $150 \mathrm{~mm} \mathrm{KCl}$ ) at $37^{\circ} \mathrm{C}$, and when necessary, at $22^{\circ} \mathrm{C}$. Figure $1 \mathrm{~A}$ represents the calibration curve of a KISE, which shows potential response of the microelectrode filled with potassium ionophore $\left(V_{\mathrm{K}}\right)$ versus $\mathrm{K}^{+}$activity of the test solution. The activity coefficient of $\mathrm{K}^{+}$was regarded as to be 0.75 . The average slope of the electrodes was $54.3 \pm 0.4 \mathrm{mV} /$ decade. The selectivity coefficient $\left(k_{\mathrm{K}-\mathrm{Na}}\right)$ was calculated 
Table 2. Morphologic features of human atrial cells $(n=81)$.

\begin{tabular}{ccccc}
\hline $\begin{array}{c}\text { Length } \\
(\mu \mathrm{m})\end{array}$ & $\begin{array}{c}\text { Diameter } \\
(\mu \mathrm{m})\end{array}$ & $\begin{array}{c}\text { Surface area } \\
\left(\mu \mathrm{m}^{2}\right)\end{array}$ & $\begin{array}{c}\text { Volume } \\
\left(\mu \mathrm{m}^{3}\right)\end{array}$ & $\begin{array}{c}S / V \text { ratio } \\
\left(\mathrm{cm}^{-1}\right)\end{array}$ \\
\hline $76.6 \pm 26.3$ & $17.7 \pm 4.3$ & $3,157 \pm 1,299$ & $10,480 \pm 6,306$ & $3,335 \pm 790$ \\
\hline
\end{tabular}

Values are means \pm S.D. $S / V$ ratio: surface area divided by volume. Each parameter measured assuming smooth cell surface and each cell was a solid of revolution around the central longitudinal axis.

by the Nicolsky equation, for the mixed electrolyte solution (see LEE, 1981). The calculated values were less than 0.01 .

Recording techniques. Double-barreled microelectrodes, with one barrel containing potassium ionophore, and the other $\mathrm{NaCl}$, were connected to each input probe of a high input-impedance amplifier (WPI FD 223-D). An Ag-AgCl electrode embedded in $3 \%$ agar- $3 \mathrm{M} \mathrm{KCl}$ was used to ground the bath. To measure the intracellular potassium activity, $a_{\mathrm{K}}^{\mathrm{i}}$, potential from the $\mathrm{NaCl}$-filled reference barrel $\left(V_{\mathrm{m}}\right)$ was subtracted from that of the $\mathrm{K}^{+}$selective barrel $\left(V_{\mathrm{K}}\right)$. All outputs were monitored with digital voltmeters built-in the amplifier, and a digital memory oscilloscope (Kikusui, DSS-5020A), and were displayed on a pen chart recorder (Nihon Kohden, WT645G).

Estimations of cell volume and cell surface area. The atrial tissue blocks excised from 4 patients were fixed in a mixed solution of glutaraldehyde and osmium tetroxide at the slack length, dehydrated in ethanol, and embedded in epoxy resin. Thin sections were examined in a JEM-100x electron microscope, and pictures were taken at an original magnification of 660 and then enlarged as desired. The cells, when sectioned horizontally to the long axis over the entire length with the cut end of the nucleus in the center, were accepted for measurement. Assuming that the human atrial cell was a solid of revolution, we calculated the volume and the surface area of the cell, by marking the contour of the cell and measuring the radius in every section over the entire length of the cell, with the help of a digitizer (Kd4030, Graphtec, Tokyo). Every cross-section area thus obtained was integrated over the whole cell length by a computer (PC9801, NEC, Tokyo), to provide cell volume and cell surface area. These values, including the average length and diameter of the cells, are listed on Table 2. The length and diameter of human atrial cells obtained here were compatible with those reported previously in similar specimens (Truex, 1972; EsCANDE et al., 1987).

Statistical analysis. The significant difference of mean values was analyzed using the paired Student's $t$-test, and the difference was considered significant at a $p$ value less than 0.05 . 


\section{RESULTS}

Intracellular $K^{+}$activity $\left(a_{\mathrm{K}}^{\mathrm{i}}\right)$ and resting membtane potential $\left(V_{\mathrm{m}}\right)$ in diseased human atrial preparations

After 60-min incubation in normal Tyrode's solution $\left(5.4 \mathrm{~mm}[\mathrm{~K}]_{\mathrm{o}}\right), a_{\mathrm{K}}^{\mathrm{i}}$ and $V_{\mathrm{m}}$ in non-driven atrial fiber were recorded simultaneously using double-barreled $\mathrm{K}^{+}$-selective microelectrodes (KISEs). In Fig. 2, the $a_{\mathrm{K}}^{\mathrm{i}}$ (log-scale) is plotted against $V_{\mathrm{m}}$ in 33 preparations. Each point represents the averaged value of all (3-10) impalements in one preparation. The $a_{\mathrm{K}}^{\mathrm{i}}$ averaged $99.7 \pm 1.3 \mathrm{~mm}$ (mean \pm S.E., $n=33$, range 80.8 to $111.2 \mathrm{mM}$ ). This value was much the same as values reported for heart muscles from intact animals (rabbit, $87.0 \mathrm{~mm}$ reported by SKINNER and KUNZE, 1976; guinea pig, $102.1 \mathrm{~mm}$ by BAUMGARTEN et al., 1984). In contrast, $V_{\mathrm{m}}$ was partially depolarized $(-43.9 \pm 1.4 \mathrm{mV}, n=33)$, and distributed over a wide range $(-75.0$ to $-32.5 \mathrm{mV})$. The dashed line shows the regression line between $a_{\mathrm{K}}^{\mathrm{i}}$ and $V_{\mathrm{m}}$ estimated using the least-squares method $\left(V_{\mathrm{m}}=15.6 \log \left(a_{\mathrm{K}}^{\mathrm{i}}\right)-75.1, r=0.06\right)$, thereby indicating no significant correlation between $a_{\mathrm{K}}^{\mathrm{i}}$ and $V_{\mathrm{m}}$. Such findings suggest that: 1) the partial depolarization was not due to a decrease in $[\mathrm{K}]_{\mathrm{i}}$; and 2) Na-K pump in the resting membrane appears to be normally operating, despite considerable decreases in $V_{\mathrm{m}}$. Substitution of the measured values of intra- and extracellular $\mathrm{K}^{+}$activity into the Nernst equation gave the $V_{\mathrm{m}}$ of $-85.6 \mathrm{mV}$, which

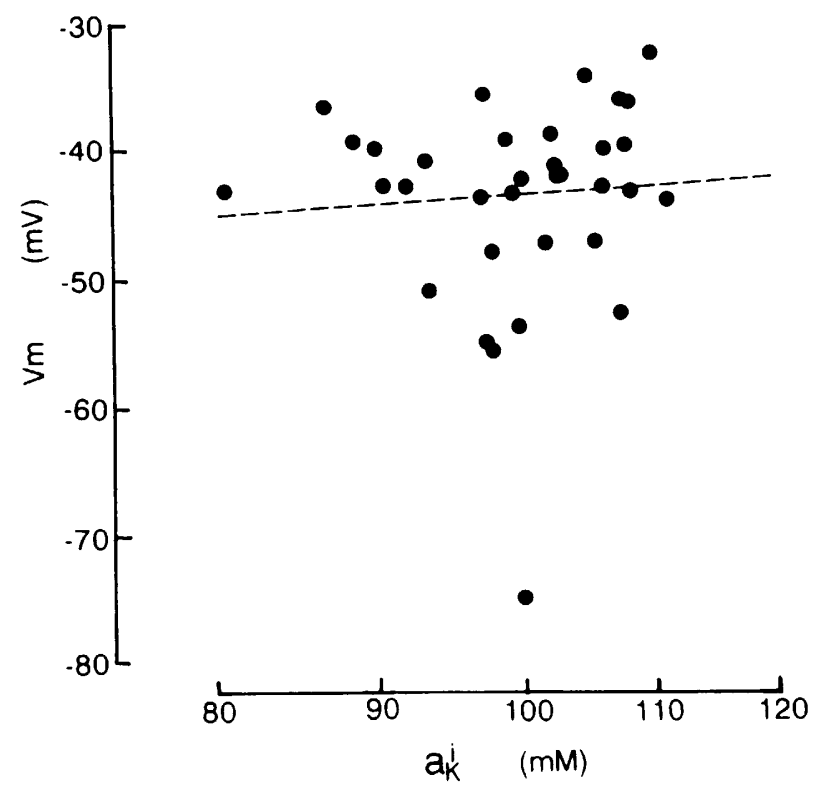

Fig. 2. Relations between $a_{\mathrm{K}}^{\mathrm{i}}$ and $V_{\mathrm{m}}$ in 33 preparations. Each point, average values obtained from multiple impalements of a single specimen. Dashed line, regression line, estimated using least-squares method; $V_{\mathrm{m}}=15.6 \log \left(a_{\mathrm{K}}^{\mathrm{i}}\right)-75.1$ (coefficient of correlation, $r=0.06$ ). 
approximately doubled the actual $V_{\mathrm{m}}(-43.9 \mathrm{mV})$.

\section{Effect of dihydro-ouabain (DHO) on $a_{\mathrm{k}}^{\mathrm{i}}$ and $V_{\mathrm{m}}$}

The threshold concentration of DHO to increase the $a_{\mathrm{Na}}^{\mathrm{i}}$ by inhibiting the Na-K pump is about $10^{-7} \mathrm{M}$ (DEITMER and Ellis, 1978) and the effect disappeared at a rate 10 times faster than that of ouabain after washout (BACH and REITER, 1964). Thus, we studied the effects of DHO at concentrations of $10^{-6}$ and $10^{-5} \mathrm{M}$ on $a_{\mathrm{K}}^{\mathrm{i}}$ and $V_{\mathrm{m}}$, followed by washout. As shown in the upper trace of Fig. 3A, DHO $\left(10^{-5} \mathrm{M}\right)$ produced a gradual decrease in $a_{\mathrm{K}}^{\mathrm{i}}$ from its initial value of $84.8 \mathrm{mM}$ to a steady state level of $80.2 \mathrm{mM}$ in approximately $20 \mathrm{~min}$. Figure $3 \mathrm{~B}$ summarizes the results of the changes in $a_{\mathrm{K}}^{\mathrm{i}}$ obtained from 4 similar experiments, in which DHO significantly decreased $a_{\mathrm{K}}^{\mathrm{i}}$ from $95.3 \pm 3.6$ to $91.5 \pm 3.0 \mathrm{mM}$ within $5 \mathrm{~min}$, and then to $88.3 \pm 2.8 \mathrm{~mm}$ in $20 \mathrm{~min}$. The low concentration of DHO $\left(10^{-6} \mathrm{M}\right)$ had less effect but still significantly decreased $a_{\mathrm{K}}^{\mathrm{i}}$ by $3.0 \pm 0.3 \mathrm{mM}(n=4)$ within $20 \mathrm{~min}$ (not shown in Fig. 3). In contrast, the $V_{\mathrm{m}}$ was typically affected in biphasic manner after application of DHO, as shown in Fig. 3A (bottom trace). In the first 5 to $7 \mathrm{~min}$ after application, DHO $\left(10^{-5} \mathrm{M}\right)$ decreased $V_{\mathrm{m}}$ by $3.9 \pm 0.5 \mathrm{mV}$ on average, i.e., from $-36.6 \pm 0.8$ to $-32.7 \pm 1.0 \mathrm{mV}(n=4, p<0.01)$, while the lower DHO concentration $\left(10^{-6} \mathrm{M}\right)$ produced much less but still significant depolarization by $0.8 \pm 0.1 \mathrm{mV}(n=4, p<0.05)$. After this depolarization, however, the $V_{\mathrm{m}}$ tended to hyperpolarize with time. Actually, in 4 of 8 preparations tested in the presence of DHO at $10^{-6}$ or $10^{-5} \mathrm{M}$, the $V_{\mathrm{m}}$ did hyperpolarize by $1.4 \pm 1.0 \mathrm{mV}(n=4)$, compared to the $V_{\mathrm{m}}$ just prior to DHO application. These changes in $a_{\mathrm{K}}^{\mathrm{i}}$ and $V_{\mathrm{m}}$ could be reversed within 15 min after washout of the drug.

Effects of altered extracellular $K^{+}$concentrations $\left([K]_{\mathrm{o}}\right)$ on $a_{\mathrm{K}}^{\mathrm{i}}$ and $V_{\mathrm{m}}$

If the $\mathrm{Na}-\mathrm{K}$ pump is operating in the resting membrane of human atrial preparations, changes in $a_{\mathrm{K}}^{\mathrm{i}}$ and $V_{\mathrm{m}}$ should be expected when the pump is inhibited by introduction of low $[\mathrm{K}]_{\mathrm{o}}$. Figure $4 \mathrm{~A}$ represents one such experiment. Reduction of $[\mathrm{K}]_{\mathrm{o}}$ from 5.4 to $0.5 \mathrm{mM}$, decreased $a_{\mathrm{K}}^{\mathrm{i}}$ by $3.8 \mathrm{mM}$ and decreased $V_{\mathrm{m}}$ by $3.9 \mathrm{mV}$. On return to $5.4 \mathrm{mM}[\mathrm{K}]_{\mathrm{o}}$, the $a_{\mathrm{K}}^{\mathrm{i}}$ recovered to control level and $V_{\mathrm{m}}$ was transiently increased to a maximum level $-48.1 \mathrm{mV}$, which exceeded, by $8.2 \mathrm{mV}$, the $V_{\mathrm{m}}$ prior to introduction of $0.5 \mathrm{~mm}[\mathrm{~K}]_{\mathrm{o}}(-39.9 \mathrm{mV})$. This maximum hyperpolarization $(-48.1 \mathrm{mV})$ was then followed by a gradual return to the steady state $V_{\mathrm{m}}$ at $5.4 \mathrm{~mm}$ $[\mathrm{K}]_{\mathrm{o}}(-40.2 \mathrm{mV})$. Figure $4 \mathrm{~B}$ summarizes the results of changes in $a_{\mathrm{K}}^{\mathrm{i}}$ in 11 similar experiments, in which reduction of $[\mathrm{K}]_{\mathrm{o}}$ from 5.4 to $0.5 \mathrm{~mm}$ significantly decreased $a_{\mathrm{K}}^{\mathrm{i}}$ from $104.0 \pm 2.6$ to $95.1 \pm 2.6 \mathrm{mM}$. The resumption of $a_{\mathrm{K}}^{\mathrm{i}}$ to $104.0 \pm 2.4 \mathrm{mM}$, very close to the control value, occurred within $10 \mathrm{~min}$ after return to $5.4 \mathrm{mM}[\mathrm{K}]_{\mathrm{o}}$. This recovery of $a_{\mathrm{K}}^{\mathrm{i}}$ along with transient hyperpolarization of $V_{\mathrm{m}}$ is considered to be due to activation of the electrogenic $\mathrm{Na}-\mathrm{K}$ pump upon exposure to high $[\mathrm{K}]_{\mathrm{o}}(5.4 \mathrm{~mm})$ after being partially suppressed by the perfusion with low $[\mathrm{K}]_{\mathrm{o}}(0.5 \mathrm{~mm})$. 


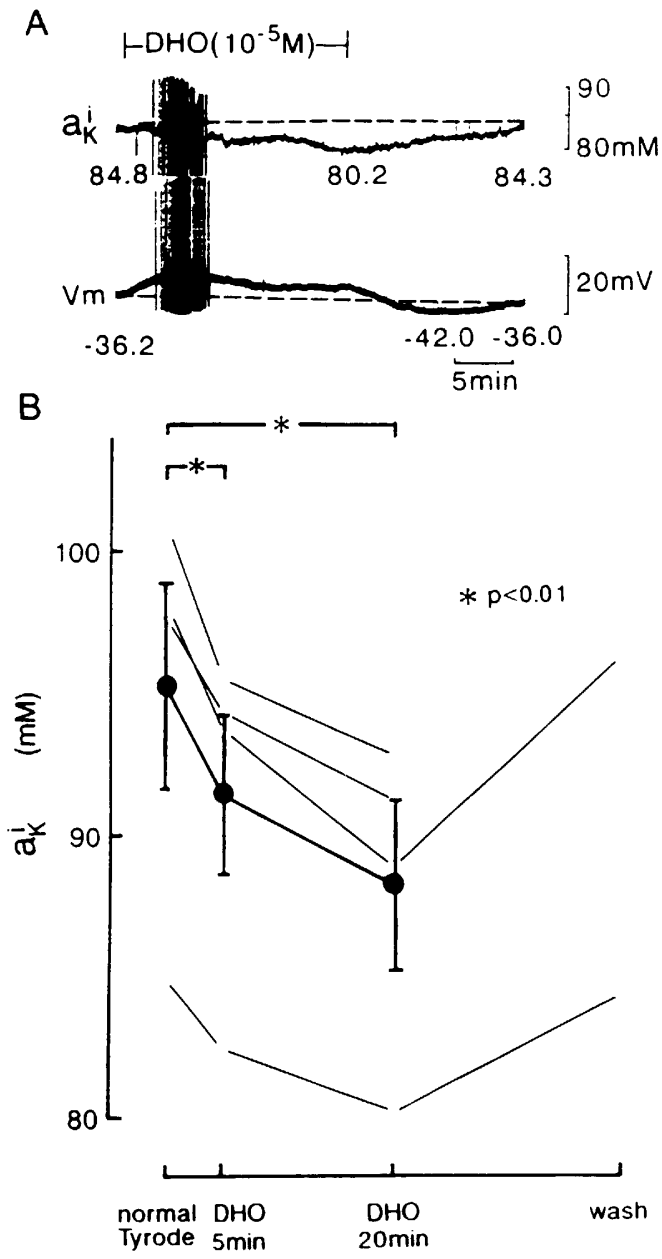

Fig. 3. Effects of diliydro-ouabain (DHO) on $a_{\mathrm{K}}^{\mathrm{i}}$ and $V_{\mathrm{m}}$. A: simultaneous recording of $a_{\mathrm{K}}^{\mathrm{i}}$ (upper trace) and $V_{\mathrm{m}}$ (lower trace), when exposed to $10^{-5} \mathrm{M}$ DHO during period indicated by horizontal bar at the top $(20 \mathrm{~min})$. B: summarized effects of DHO on $a_{\mathrm{K}}^{\mathrm{i}}$. Each solid line, different preparation tested. Solid circles connected by heavy solid lines, mean value obtained from 4 individual experiments. Vertical bars, S.E. Asterisk, significant differences from the control (before application of DHO).

Inhibition of high $[K]_{\mathrm{o}}$-induced increases in $a_{\mathrm{K}}^{\mathrm{i}}$ and $V_{\mathrm{m}}$

1) Effects of $\mathrm{DHO}$. Figure $5 \mathrm{~A}$ and $\mathrm{B}$ show an experiment in which a single impalement was maintained throughout the procedures. In the absence of DHO (Fig. 5A), the elevation of $[\mathrm{K}]_{\mathrm{o}}$ from 0.5 to $5.4 \mathrm{mM}$ increased $a_{\mathrm{K}}^{\mathrm{i}}$ by $5.1 \mathrm{mM}$ and produced trasient hyperpolarization of $V_{\mathrm{m}}$, a finding identical to that in the right half of Fig. 4A. In the presence of DHO (Fig. 5B), increase in $a_{\mathrm{K}}^{\mathrm{i}}$ was abolished 


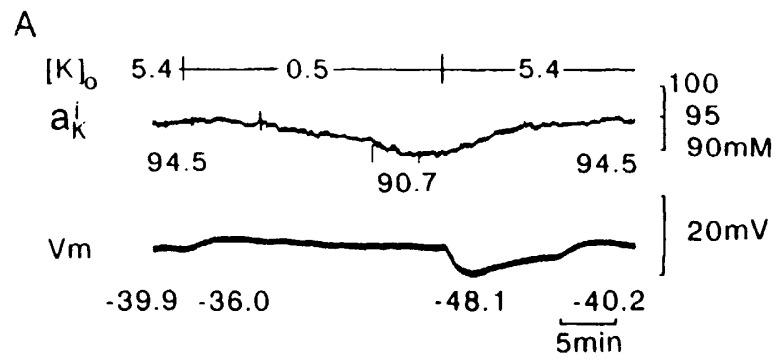

B

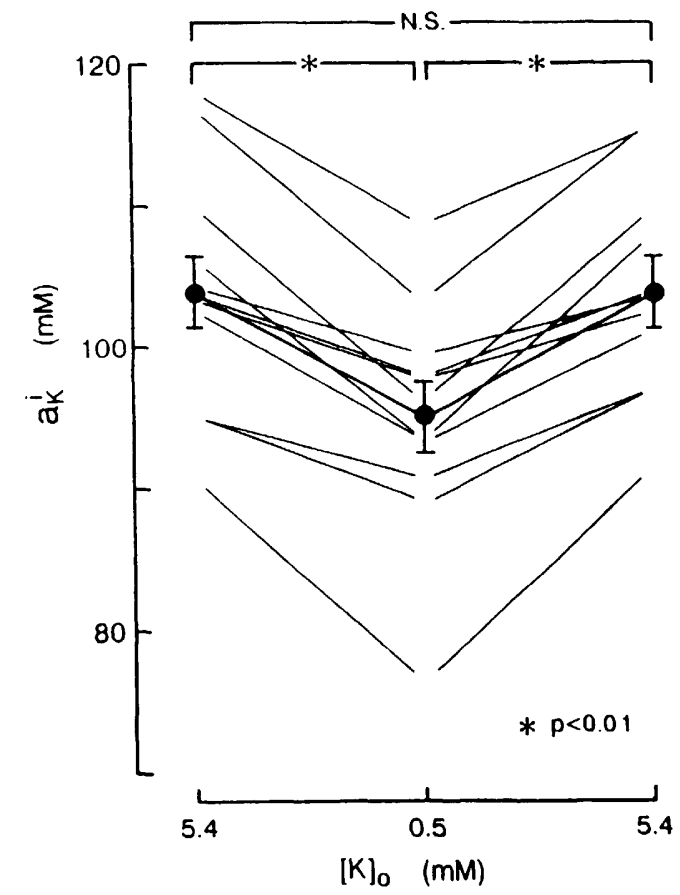

Fig. 4. Changes in $a_{\mathrm{K}}^{\mathrm{i}}$ and $V_{\mathrm{m}}$ in response to step changes of $[\mathrm{K}]_{\mathrm{o}}$. A: top trace, experimental protocol (changes of $[\mathrm{K}]_{\mathrm{o}}$ ). The $a_{\mathrm{K}}^{\mathrm{i}}$ and $V_{\mathrm{m}}$ were simultaneously recorded. B: steady state $a_{\mathrm{K}}^{\mathrm{i}}$ (ordinate) plotted against different $[\mathrm{K}]_{\mathrm{o}}$ (abscissa) for 11 preparations. Solid circles connected by heavy solid lines, averaged values. Vertical bars, S.E. Asterisk, significant difference; N. S., not significant.

and the initial transient hyperpolarization of $V_{\mathrm{m}}$ disappeared as well, but steady hyperpolarization of $V_{\mathrm{m}}$ remained. It must be noted that the steady state $V_{\mathrm{m}}$ at $5.4 \mathrm{mM}[\mathrm{K}]_{\mathrm{o}}$ in the presence of DHO $(-46.4 \mathrm{mV})$ was $3.8 \mathrm{mV}$ more negative than the steady state $V_{\mathrm{m}}$ at $5.4 \mathrm{~mm}[\mathrm{~K}]_{\mathrm{o}}$ in the absence of DHO $(-42.6 \mathrm{mV})$. Figure 6 summarizes the changes in $a_{\mathrm{K}}^{\mathrm{i}}$ in 5 similar experiments. Upon changing $[\mathrm{K}]_{\mathrm{o}}$ from 0.5 to $5.4 \mathrm{mM}$ in the absence of $\mathrm{DHO}, a_{\mathrm{K}}^{\mathrm{i}}$ increased significantly from $94.8 \pm 1.7$ to 
A Nomal Tyrode
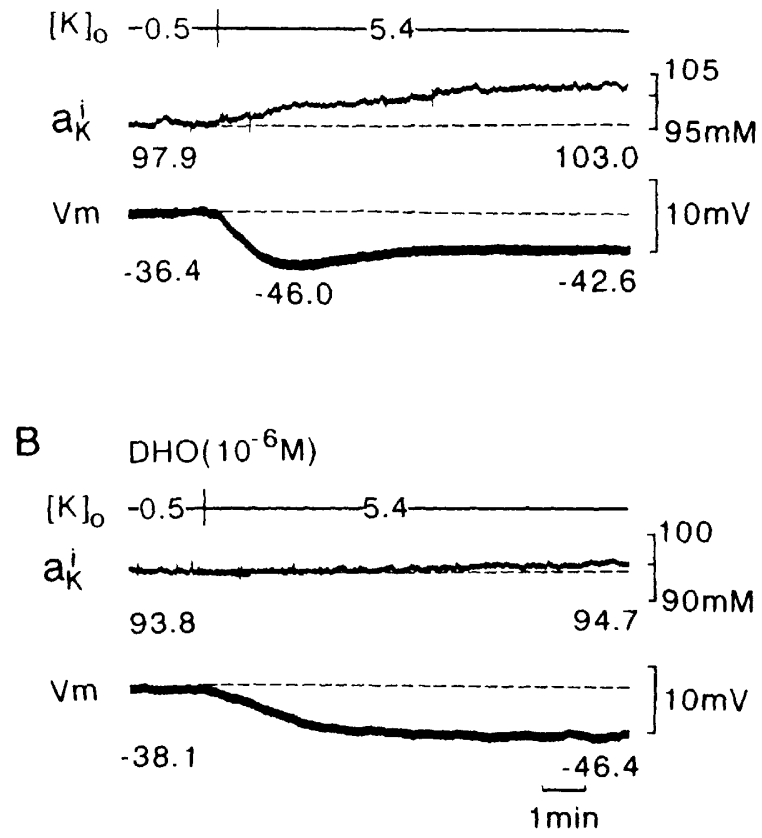

Fig. 5. Effects of DHO on high $[\mathrm{K}]_{0}$-induced increase in $a_{\mathrm{K}}^{\mathrm{i}}$ and hyperpolarization of $V_{\mathrm{m}}$. Preparation superfused with $0.5 \mathrm{~mm}[\mathrm{~K}]_{\mathrm{o}}$-Tyrode's solution switched to $5.4 \mathrm{mM}$ $[\mathrm{K}]_{\mathrm{o}}$ in the absence $(\mathrm{A})$ and presence $(\mathrm{B})$ of $10^{-6} \mathrm{M}$ DHO. Entire procedure completed during a single cell impalement. Note that transient hyperpolarization of $V_{\mathrm{m}}$ and increase in $a_{\mathrm{K}}^{i}$ (panel A) were abolished in the presence of DHO (panel B).

$104.3 \pm 2.3 \mathrm{~mm}$. In the presence of DHO, the increase in $a_{\mathrm{K}}^{\mathrm{i}}$ was not significant, i.e., $90.3 \pm 1.8 \mathrm{~mm}$ at $0.5 \mathrm{~mm}[\mathrm{~K}]_{\mathrm{o}}$ and $91.3 \pm 2.2 \mathrm{~mm}$ at $5.4 \mathrm{~mm}[\mathrm{~K}]_{\mathrm{o}}$.

2) Effects of low temperature. To study the effect of temperature on high $[\mathrm{K}]_{\mathrm{o}}$-induced increase in $a_{\mathrm{K}}^{\mathrm{i}}$ and $V_{\mathrm{m}},[\mathrm{K}]_{\mathrm{o}}$ was increased from 0.5 to $5.4 \mathrm{~mm}$ at low temperature $\left(22^{\circ} \mathrm{C}\right)$. As shown in Fig. $7 \mathrm{~A}$, the $a_{\mathrm{K}}^{\mathrm{i}}(66.8 \mathrm{~mm})$ and $V_{\mathrm{m}}(-20 \mathrm{mV})$ measured at low temperature and low $[\mathrm{K}]_{0}$ seemed fairly depressed compared to the values measured at normal temperature and low $[\mathrm{K}]_{\mathrm{o}}$ (cf. Fig. $5 \mathrm{~A}, a_{\mathrm{K}}^{\mathrm{i}} 97.9 \mathrm{~mm}$; $\left.V_{\mathrm{m}}-36.4 \mathrm{mV}\right)$. At low temperature $\left(22^{\circ} \mathrm{C}\right)$, elevation of $[\mathrm{K}]_{\mathrm{o}}$ from 0.5 to $5.4 \mathrm{~mm}$ did not appreciably change $a_{\mathrm{K}}^{\mathrm{i}}$ or $V_{\mathrm{m}}$, but increasing temperature from 22 to $37^{\circ} \mathrm{C}$ markedly increased $a_{\mathrm{K}}^{\mathrm{i}}$ (from 67.1 to $109.9 \mathrm{mM}$ ) and hyperpolarized $V_{\mathrm{m}}$. At the same time, spontaneous action potentials were elicited in 2 of 4 preparations (Fig. 7A). Figure 7B summarizes the temperature-induced changes in $a_{\mathrm{K}}^{\mathrm{i}}$ in 4 similar experiments. The $a_{\mathrm{K}}^{\mathrm{i}}$ was significantly increased (from $88.6 \pm 4.4$ to $99.9 \pm 3.9 \mathrm{mM}$ ) by changing $[\mathrm{K}]_{\mathrm{o}}$ from 0.5 to $5.4 \mathrm{~mm}$ at $37^{\circ} \mathrm{C}$ (left 2 columns in Fig. $7 \mathrm{~B}$, results similar to those shown in the left 2 columns of Fig. 6). At low temperature $\left(22^{\circ} \mathrm{C}\right)$, 


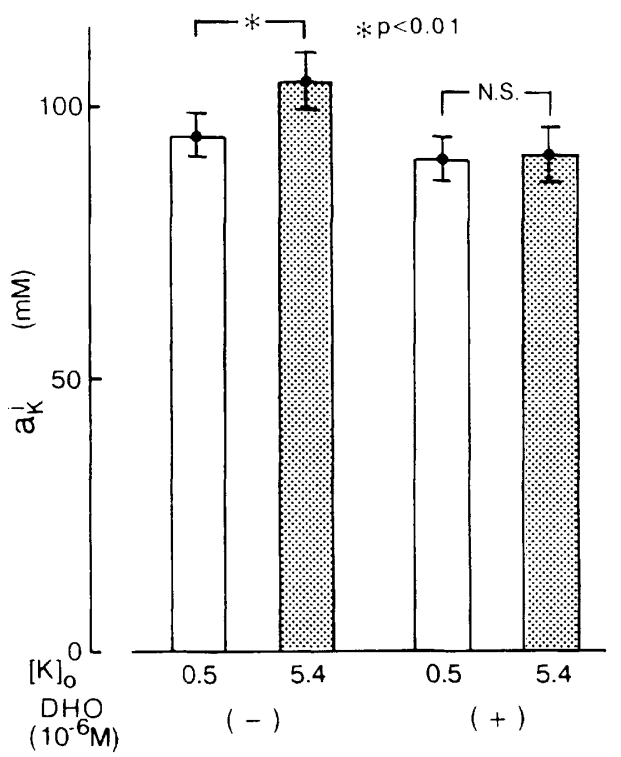

Fig. 6. Summary of effects of DHO on $a_{\mathrm{K}}^{\mathrm{i}}$ as obtained from experiments as shown in Fig. 5. Each bar, mean value of $a_{\mathrm{K}}^{\mathrm{i}}$ with S.E. (ordinate) in the absence $(-)$ and presence $(+)$ of DHO $\left(10^{-6} \mathrm{M}\right)$. Open bars, data at $0.5 \mathrm{~mm}[\mathrm{~K}]_{0}$; shaded bars, at $5.4 \mathrm{~mm}[\mathrm{~K}]_{\mathrm{o}}$. Asterisk, significant difference between the values joined by bracket; N. S., no significant difference.

however, neither $a_{\mathrm{K}}^{\mathrm{i}}$ nor $V_{\mathrm{m}}$ was changed by the same increase of $[\mathrm{K}]_{\mathrm{o}}$ (from 0.5 to $5.4 \mathrm{mM}$ ). In contrast, subsequent increase of temperature from 22 to $37^{\circ} \mathrm{C}$ with $5.4 \mathrm{mM}[\mathrm{K}]_{\mathrm{o}}$ significantly increased $a_{\mathrm{K}}^{\mathrm{i}}(p<0.01$, right 2 columns in Fig. $7 \mathrm{~B})$.

Effects of isoproterenol (Iso) and acetylcholine (ACh) on $a_{\mathrm{K}}^{\mathrm{i}}$ and $V_{\mathrm{m}}$

Figure $8 \mathrm{~A}$ shows an example of effect of $10^{-7} \mathrm{M}$ Iso on $a_{\mathrm{K}}^{\mathrm{i}}$ and $V_{\mathrm{m}}$ in a preparation perfused in control Tyrode's solution. After application of Iso, $a_{\mathrm{K}}^{\mathrm{i}}$ slightly but significantly increased from $97.5 \pm 3.6$ to $99.6 \pm 3.8 \mathrm{~mm}(n=4, p<0.01)$, and $V_{\mathrm{m}}$ hyperpolarized by 0.5 to $3.1 \mathrm{mV}$ in all preparations tested. Figure $8 \mathrm{~B}$ shows a typical effect of ACh on $a_{\mathrm{K}}^{\mathrm{i}}$ and $V_{\mathrm{m}}$. ACh $\left(10^{-5} \mathrm{M}\right)$ did not produce a detectable change in $a_{\mathrm{K}}^{\mathrm{i}}$, but it significantly hyperpolarized the membrane potential, i.e., $V_{\mathrm{m}}$ changed from $-39.0 \pm 4.7$ to $-43.1 \pm 5.1 \mathrm{mV}(n=5, p<0.01)$. These effects produced by Iso and $\mathrm{ACh}$ were completely reversible within $3 \mathrm{~min}$ after washing out of the agents.

Estimation of $\mathrm{Na}^{+}$-efflux rate in the steady state

It is possible to calculate the rate of reduction of $\mathrm{K}^{+}$net influx $\left(\mathrm{pmol} /\left(\mathrm{cm}^{2} \cdot \mathrm{s}\right)\right)$ produced by $10^{-5} \mathrm{M}$ DHO from the following equation:

$$
\Delta[\mathrm{K}]_{\mathrm{i}} V /(S \cdot t) \quad \text { or } \quad \Delta[\mathrm{K}]_{\mathrm{i}} /\{(S / V) \cdot t\}
$$




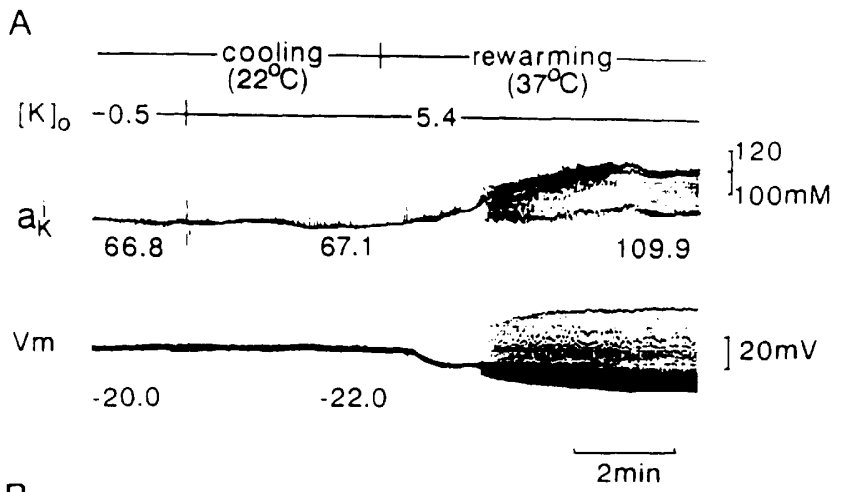

B

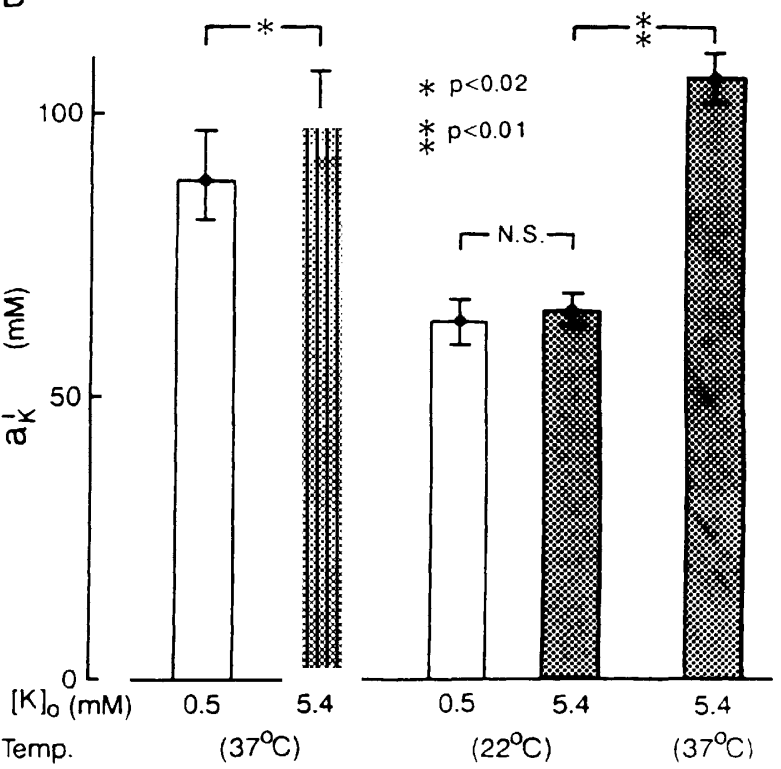

Fig. 7. Effects of cooling and rewarming on high $[\mathrm{K}]_{0}$-induced increase in $a_{\mathrm{K}}^{\mathrm{i}}$ and transient hyperpolarization of $V_{\mathrm{m}}$. A: top row, bath temperature; the second row, $[\mathrm{K}]_{\mathrm{o}}(\mathrm{mM})$. Preparation exposed to $0.5 \mathrm{mM}[\mathrm{K}]_{\mathrm{o}}$ solution at $22^{\circ} \mathrm{C}$ for $20 \mathrm{~min}$; then $[\mathrm{K}]_{\mathrm{o}}$ was increased to $5.4 \mathrm{mM}$ at this temperature. Thereafter, in $5.4 \mathrm{~mm}[\mathrm{~K}]_{\mathrm{o}}$, bath temperature was raised to $37^{\circ} \mathrm{C}$. Traces at extreme right of both $a_{\mathrm{K}}^{\mathrm{i}}$ and $V_{\mathrm{m}}$ show evolution of automatic activity. B: each bar, mean value of $a_{\mathrm{K}}^{\mathrm{i}}(n=4)$ with S.E. in response to altered change of $[\mathrm{K}]_{\mathrm{o}}(0.5 \mathrm{~mm}$, open; $5.4 \mathrm{~mm}$, shaded $)$ at altered temperature as indicated. Asterisk, significant difference between values joined by brackets.

where $\Delta[\mathrm{K}]_{\mathrm{i}}$ denotes decrease of $[\mathrm{K}]_{\mathrm{i}}$ attained by the first $5 \mathrm{~min}$ application of DHO; $S$ and $V$ are surface area and volume of the cell, respectively; and $t$ is the period of application of DHO (5min or $300 \mathrm{~s})$. Using this equation, the DHO-induced rate of reduction of $\mathrm{K}^{+}$net influx was calculated to be approximately 


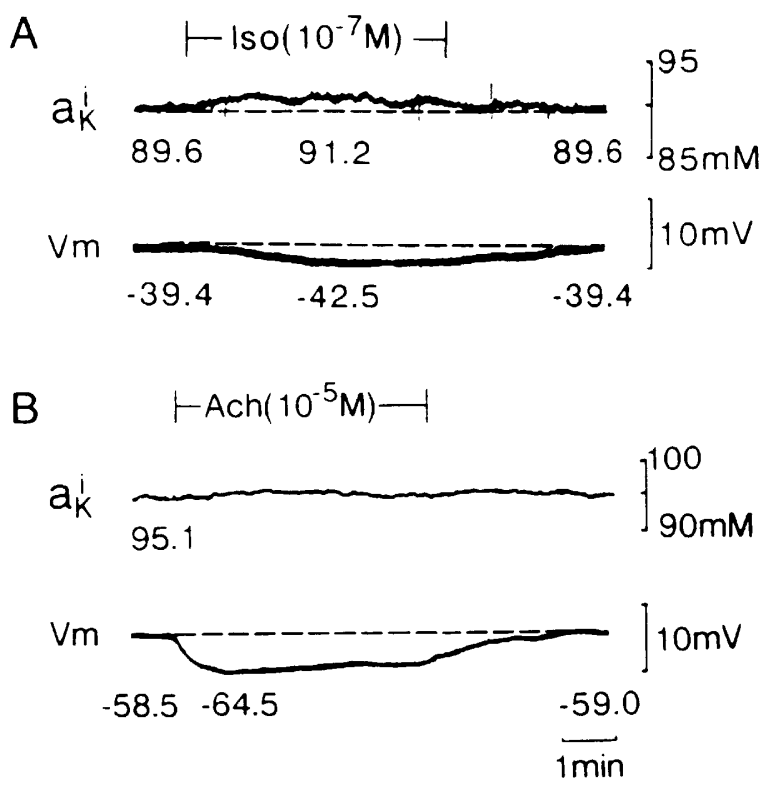

Fig. 8. Effects of isoproterenol (A) and acetylcholine (B) on $a_{\mathrm{K}}^{\mathrm{i}}$ and $V_{\mathrm{m}}$. Preparation exposed to drug as indicated at top of each panel.

$5.1 \mathrm{pmol} /\left(\mathrm{cm}^{2} \cdot \mathrm{s}\right)$, for $\Delta[\mathrm{K}]_{\mathrm{i}}$ equal to $5.1 \pm 0.8 \mathrm{~mm}$ (Fig. 3), $t$ equal to $300 \mathrm{~s}$, and $S / V$ equal to $3,335 \mathrm{~cm}^{-1}$ (Table 2). The value of surface to volume ratio, $S / V$, was somewhat less than that reported in sheep Purkinje fibers $\left(4,600 \mathrm{~cm}^{-1}\right.$, MOBLEY and PAGE, 1972). Since the photographically measured $S$ may be half to one third of the actual $S$, due to existence of T-tubules and sarcolemmal caveolae (GADSBY et al., 1985), the true rate of reduction of $\mathrm{K}^{+}$net influx per unit membrane area could be half to one third of 5.1 , or 1.7 to $2.6 \mathrm{pmol} /\left(\mathrm{cm}^{2} \cdot \mathrm{s}\right)$. Therefore, the rate of reduction of $\mathrm{Na}^{+}$-efflux during a 5-min application of $10^{-5} \mathrm{M}$ DHO is estimated to be $2.6-3.8 \mathrm{pmol} /\left(\mathrm{cm}^{2} \cdot \mathrm{s}\right)$, since $\mathrm{Na}^{+}$and $\mathrm{K}^{+}$are likely to exchange at a coupling ratio of 3 to 2 in cardiac muscle.

\section{DISCUSSION}

The resting membrane potential of the right atrial muscle excised from the patients with congenital or acquired heart disease ("diseased atrial muscle") is generally decreased, probably due to chronic hemodynamic overload or ischemia that might have been imposed on the atrium for a long period of time (MARY-RABINE et al., 1983; LEE, 1986; IMANISHI and ARITA, 1987). In the present study using such "diseased right atrial muscles," we measured $a_{\mathrm{K}}^{\mathrm{i}}$ and $V_{\mathrm{m}}$ in non-driven conditions and found the $a_{\mathrm{K}}^{\mathrm{i}}$ to be $99.7 \pm 1.3 \mathrm{mM}$ and the $V_{\mathrm{m}},-43.9 \pm 1.4 \mathrm{mV}$. This $a_{\mathrm{K}}^{\mathrm{i}}$ is comparable to those estimated for spontaneously active human atrial fibers $(98.1 \mathrm{~mm}$ 
in $4.0 \mathrm{~mm}[\mathrm{~K}]_{\mathrm{o}}$, MCCullough et al., 1987) and intact atrial muscle preparations of other species (rabbit, $87.0 \mathrm{~mm}$ in $3.6 \mathrm{~mm}[\mathrm{~K}]_{\mathrm{o}}$, SKINNER and KUNZE, 1976; guinea pig, $102.1 \mathrm{~mm}$ in $5.0 \mathrm{~mm}[\mathrm{~K}]_{0}$, BAUMGARTEN et al., 1984). It was reported that the $V_{\mathrm{m}}$ of "diseased" human atrial fibers is partially depolarized and is distributed over a wide range (MARY-RABINE et al., 1983; LeE, 1986; IMANISHI and ARITA, 1987). This was also true in the present study (Fig. 2). Since there is no significant correlation between $V_{\mathrm{m}}$ and $a_{\mathrm{K}}^{\mathrm{i}}$ (Fig. 2), variation of depolarization may not be attributed to variation of $a_{\mathrm{K}}^{\mathrm{i}}$. In fact, we found that $a_{\mathrm{K}}^{\mathrm{i}}$ of a certain well-polarized cell $\left(V_{\mathrm{m}}=-75.0 \mathrm{mV}\right)$ was $100.0 \mathrm{~mm}$, while that of a markedly depolarized cell $\left(V_{\mathrm{m}}=-32.5 \mathrm{mV}\right)$ had much higher $a_{\mathrm{K}}^{\mathrm{i}}(110.0 \mathrm{mM})$. Therefore, the mechanism of $V_{\mathrm{m}}$ decrease should be attributed to some factor(s) other than lowered $a_{\mathrm{K}}^{\mathrm{i}}$, that is, decrease in membrane $\mathrm{K}^{+}$conductance (MARY-RABINE et al., 1983; IMANISHI and ARITA, 1987) and increase in $\mathrm{Na}^{+}$conductance (IMANISHI and ARITA, 1987).

The finding that $a_{\mathrm{K}}^{\mathrm{i}}$ remained at physiological levels suggests that the $\mathrm{Na}-\mathrm{K}$ pump is unaffected and functions normally, even in diseased human atrial muscles, and that the outward current caused by electrogenic property of the Na-K pump may affect the $V_{\mathrm{m}}$. However, measurement of changes in $V_{\mathrm{m}}$ is not relevant to assess the pump function, because "diseased" human atrial fibers had remarkable alteration in the membrane conductance (TEN EICK and Singer, 1979; MARY-RABINE et al., 1983; IMANISHI and ARITA, 1987). Therefore, direct measurement of intracellular $\mathrm{K}^{+}$activity seems to be a more appropriate approach to investigate $\mathrm{Na}-\mathrm{K}$ pump function in such preparations.

Exposure to $10^{-5} \mathrm{M}$ DHO produced a significant decrease in $a_{\mathrm{K}}^{\mathrm{i}}$ and some depolarization of $V_{\mathrm{m}}$ in the early phase of drug application (Fig. 3). These effects are considered to be due to inhibition of the Na-K pump (DeITMER and ElLIS, 1978). Similarly, a decrease in $[\mathrm{K}]_{\mathrm{o}}$ from 5.4 to $0.5 \mathrm{~mm}$ also produced a significant reduction in the $a_{\mathrm{K}}^{\mathrm{i}}$ and a slight depolarization of $V_{\mathrm{m}}$ (Fig. 4A and B). However, in the latter case, depolarization of $V_{\mathrm{m}}$ may be also attributed to a decrease in $\mathrm{K}^{+}$ conductance, because lowered $[\mathrm{K}]_{\mathrm{o}}$ decreases $\mathrm{K}^{+}$conductance (TEN EICK and SingER, 1979; IMANISHI and ARITA, 1987). In contrast, an increase in $[\mathrm{K}]_{\mathrm{o}}$ from 0.5 to $5.4 \mathrm{~mm}$ produced a significant increase in $a_{\mathrm{K}}^{\mathrm{i}}$ and transient hyperpolarization which exceeded the steady state levels of $V_{\mathrm{m}}$ at $5.4 \mathrm{~mm}[\mathrm{~K}]_{\mathrm{o}}$ by about $8 \mathrm{mV}$. Furthermore, both the increase in $a_{\mathrm{K}}^{\mathrm{i}}$ and initial hyperpolarization induced by this increase in $[\mathrm{K}]_{\mathrm{o}}$ were inhibited in the presence of $10^{-6} \mathrm{M}$ DHO or at low temperature $\left(22^{\circ} \mathrm{C}\right)$ (Figs. 5-7). This finding is in keeping with the idea that DHO or low temperature inhibits the activation of the Na-K pump that otherwise should be activated by an increase in $[\mathrm{K}]_{\mathbf{o}}$. The Na-K ATPase is highly dependent on the temperature (PALATINI et al., 1977) and the low temperature decreases the activity of the Na-K pump (SperelaKis and LeE, 1971). In fact, Na-K ATPase activity of bovine heart preparation measured at $22^{\circ} \mathrm{C}$ was markedly depressed, to be about $5 \%$ of that measured at $37^{\circ} \mathrm{C}$ (Fig. 3 in Palatini et al., 1977). Lowering the temperature from 37 to $20^{\circ} \mathrm{C}$ also decreased the outward pump current, that was comparable to the effect produced by $2 \times 10^{-5} \mathrm{M}$ DHO (ISENBERG and TRAUTWEIN, 
1975). Such high dependency of Na-K pump function on the temperature may explain relatively marked decreases in $a_{\mathrm{K}}^{\mathrm{i}}$ and $V_{\mathrm{m}}$ produced by low temperature (Fig. 7), as compared to the effects produced by DHO (Fig. 3) or low [K] (Fig. 4). Therefore, it is not surprising that the decreases in $a_{\mathrm{K}}^{\mathrm{i}}$ and $V_{\mathrm{m}}$ attained at low temperature in physiologic $[\mathrm{K}]_{\mathrm{o}}(5.4 \mathrm{~mm})$ were dramatically reversed after rewarming the preparation (Fig. 7).

Isoproterenol $\left(10^{-7} \mathrm{M}\right)$ caused a significant increase in $a_{\mathrm{K}}^{\mathrm{i}}$ and slight hyperpolarization in all preparations tested (Fig. 8A), a finding compatible with the stimulation of the electrogenic Na-K pump activity. Catecholamine stimulates the electrogenic pump in cardiac muscles of bullfrog (AKASU et al., 1978) and human (IMANISHI and ARITA, 1987), and in rabbit cardiac myocytes (DÉsILETS and BAUMGARTEN, 1986). There is an alternative explanation that isoproterenol increases the membrane $\mathrm{K}^{+}$conductance (GADSBY, 1983; NeTO and SPERELAKIS, 1989) to increase the $V_{\mathrm{m}}$. However, it is difficult to explain the increase in $a_{\mathrm{K}}^{\mathrm{i}}$ by this mechanism. Recently, it was reported that $\beta$-adrenergic stimulation increases a $\mathrm{Cl}^{-}$ conductance, and thereby depolarizes the $V_{\mathrm{m}}$ (BAHINSKI et al., 1989; HARVEY and Hume, 1989). However, in our preparations Iso $\left(10^{-7} \mathrm{M}\right)$ did not depolarize the $V_{\mathrm{m}}$ but tended to hyperpolarize it. The resting membrane potential of diseased human atrial muscle was about $-44 \mathrm{mV}$ as mentioned, which was close to alleged reversal potential of the $\mathrm{Cl}^{-}$current ( -40 to $-50 \mathrm{mV}$, cf. Harvey and Hume, 1989). Therefore, the depolarization would be minimal, if any, or it would have been set off by the pump-induced hyperpolarization, in the present study.

Acetylcholine $\left(10^{-5} \mathrm{M}\right)$ significantly hyperpolarized $V_{\mathrm{m}}$ with no detectable change in $a_{\mathrm{K}}^{\mathrm{i}}$ (Fig. 8B). This may be attributed to increases in membrane $\mathrm{K}^{+}$ conductance $\left(g_{\mathrm{K}}\right)$ via activation of ACh-stimulated $\mathrm{K}^{+}$channels (IIJIMA et al., 1985).

The biphasic hyperpolarization found after increasing $[\mathrm{K}]_{\mathrm{o}}$ from 0.5 to $5.4 \mathrm{~mm}$ (Fig. 5A) may be explained as follows: 1) The initial, transient component of hyperpolarization is mainly due to activation of the $\mathrm{Na}-\mathrm{K}$ pump current, associated partly with increased membrane $\mathrm{K}^{+}$conductance produced by elevated $[\mathrm{K}]_{\mathrm{o}}$; and 2) The late, sustained hyperpolarization is most likely due to continued increase in the membrane $\mathrm{K}^{+}$conductance, in that the latter effect might have exceeded the depolarization due to decreased $\mathrm{K}^{+}$equilibrium potential (IMANISHI and ARITA, 1987).

It is worth noting that the steady state $V_{\mathrm{m}}$ at $5.4 \mathrm{~mm}[\mathrm{~K}]_{\mathrm{o}}$ in the presence of DHO $(-46.4 \mathrm{mV})$ exceeded that in the absence of DHO $(-42.6 \mathrm{mV})$ (Fig. 5). The phenomenon seems to be related to the finding that the depolarization induced by DHO at $5.4 \mathrm{~mm}[\mathrm{~K}]_{\mathrm{o}}$ was not progressive but, after some period (about $5 \mathrm{~min}$ ), turned toward re- or hyper-polarization, in spite of continuous reduction of $a_{\mathrm{K}}^{\mathrm{i}}$ (Fig. 3A). The first effect of the drug (depolarization of $V_{\mathrm{m}}$ ) seemed to be due to inhibition of electrogenic (outward) Na-K pump current by DHO, while the late effect, i.e., change of $V_{\mathrm{m}}$ in the hyperpolarizing direction, may be due to long-lasting application of DHO, which increased intracellular $\mathrm{Na}^{+}$and $\mathrm{Ca}^{2+}$ concentrations, both of which secondarily enhanced membrane $\mathrm{K}^{+}$conductance (ISENBERG, 1976; EISNER et al., 
1984; Kameyama et al., 1984; Neto and Sperelakis, 1989). Thus, in Fig. 5, the steady state $V_{\mathrm{m}}$ in the presence of DHO exceeded, regardless of slight decreases in $a_{\mathrm{K}}^{\mathrm{i}}$, the steady state $V_{\mathrm{m}}$ in the absence of DHO.

All of these data support the idea that the electrogenic Na-K pump is not impaired and operates well even in "diseased" human atrial muscles. To analyze the role of Na-K pump more quantitatively, we estimated DHO-induced decrease in the $\mathrm{Na}^{+}$-efflux rate, using the rate of decrease in $a_{\mathrm{K}}^{\mathrm{i}}$ occurring during the first 5 min exposure to DHO. The DHO-induced decrease in $\mathrm{Na}^{+}$-efflux was estimated to be $2.6-3.8 \mathrm{pmol} /\left(\mathrm{cm}^{2} \cdot \mathrm{s}\right.$ ) (see SHEU et al., 1981). This value is in keeping with the estimation for cardiac Purkinje fibers in the presence of $10^{-5} \mathrm{M}$ DHO (about $3 \mathrm{pmol} /\left(\mathrm{cm}^{2} \cdot \mathrm{s}\right)$, ISENBERG and TrAUTWEIN, 1974), suggesting again that the Na-K pump functions normally in the "diseased" or "depolarized" human preparations that we used in the present study.

We thank Dr. N. Hotokebuchi and Professor K. Nishi of the Department of Pharmacology, Kumamoto University Medical School, for guidance in fabricating the ionselective microelectrode, and to Ms. K. Takahashi and Ms. K. Goto for secretarial assistance.

\section{REFERENCES}

Akasu, T., OHta, Y., and Koketsu, K. (1978) The effect of adrenaline on the electrogenic $\mathrm{Na}^{+}$pump in cardiac muscle cells. Experientia, 34: 488-490.

BACH, E. J. and REITER, M. (1964) The difference in velocity between the lethal and inotropic action of dihydrodigoxin. Naunyn-Schmiedeberg's Arch. Exp. Pathol. Pharmakol., 248: $437-449$.

Bahinski, A., Nairn, A. C., Greengard, P., and Gadsby, D. C. (1989) Chloride conductance regulated by cyclic AMP-dependent protein kinase in cardiac myocytes. Nature, 340: 718-721.

Baumgarten, C. M., Singer, D. H., and Fozzard, H. A. (1984) Intra- and extracellular potassium activities, acetylcholine and resting potential in guinea pig atria. Circ. Res., 54: $65-73$.

Deitmer, J. W. and Eluis, D. (1978) The intracellular sodium activity of cardiac Purkinje fibers during inhibition and re-activation of the Na-K pump. J. Physiol. (Lond.), 284: 241-259.

Desilets, M. and BAumgarten, C. M. (1986) Isoproterenol directly stimulates tha $\mathrm{Na}^{+}-\mathrm{K}^{+}$ pump in isolated cardiac myocytes. Am. J. Physiol., 251: H218-H225.

Eisner, D. A., Lederer, W. J., and Vaughan-Jones, R. D. (1984) The electrogenic Na pump in mammalian cardiac muscle. In: Electrogenic Transport: Fundamental Principles and Physiological Implications, ed. by Blaustein, M. P. and Lieberman, M., Raven Press, New York, pp. 193-213.

Escande, D., Coulombe, A., Faivre, J. F., Deroubaix, E., and Coraboeuf, E. (1987) Two types of transient outward currents in adult human atrial cells. Am. J. Physiol., 252: H142-H148.

GADSBY, D. C. (1983) $\beta$-Adrenoceptor agonists increase membrane $\mathrm{K}^{+}$conductance in cardiac Purkinje fibers. Nature, 306: 691-693. 
Gadsby, D. C., Kimura, J., and Noma, A. (1985) Voltage dependence of Na-K pump current in isolated heart cells. Nature, 315: 63-65.

GlitsCH, H. G. (1979) Characteristics of active $\mathrm{Na}^{+}$transport in intact cardiac cells. Am. J. Physiol., 236: H189-H199.

Harvey, R. D. and Hume, J. R. (1989) Autonomic regulation of a chloride current in heart. Science, 244: 983-985.

Hotokebuchi, N., Yano, T., Nishizono, Y., and Nishi, K. (1987) Changes in intra- and extracellular potassium and intracellular sodium activities induced by repetitive stimulation and their relation to membrane potential in guinea-pig papillary muscle. Jpn. J. Physiol., 37: 797-819.

Ijima, T., Irisawa, H., and KameYama, M. (1985) Membrane currents and their modification by acetylcholine in isolated single atrial cells of the guinea-pig. J. Physiol (Lond.), 359: 485-501.

ImANiSHI, S. and ARITA, M. (1987) Factors related to the low resting membrane potentials of diseased human atrial muscles. Jpn. J. Physiol., 37: 393-410.

IsenberG, G. (1977) Cardiac Purkinje fibers, $\left[\mathrm{Ca}^{2+}\right]_{\mathbf{i}}$ controls steady state potassium conductance. Pflügers Arch., 371: 71-76.

IsENBERG, G. and Trautwein, W. (1974) The effect of dihydro-ouabain and lithium-ions on the outward current in cardiac Purkinje fibers. Pflügers Arch., 350: 41-54.

IsenberG, G. and Trautwein, W. (1975) Temperature sensitivity of outward current in cardiac Purkinje fibers. Evidence for electrogenicity of active transport. Pflügers Arch., 358: $225-234$.

Kameyama, M., Kakei, M., Sato, R., Shibasaki, T., Matsuda, H., and Irisawa, H. (1984) Intracellular $\mathrm{Na}^{+}$activates a $\mathrm{K}^{+}$channel in mammalian cardiac cells. Nature, 309: $354-356$.

LEE, C. O. (1981) Ionic activities in cardiac muscle cells and application of ion-selective microelectrodes. Am. J. Physiol., 241: H459-H478.

LEE, Y. S. (1986) Pathophysiological mechanisms of altered transmembrane potentials in diseased human atria. J. Electrocardiol., 19: 41-50.

Mary-Rabine, L., Albert, A., Pham, T. D., Hordof, A., Fenoglio, J. J., Jr., Malm, J. R., and Rosen, M. R. (1983) The relationship of human atrial cellular electrophysiology to clinical function and ultrastructure. Circ. Res., 52: 188-199.

McCullough, J. R., Baumgarten, C. M., and Singer, D. H. (1987) Intra- and extracellular potassium activities and the potassium equilibrium potential in partially depolarized human atrial cells. J. Mol. Cell Cardiol., 19: 477-486.

Mobley, B. A. and PAge, E. (1972) The surface area of sheep cardiac Purkinje fibers. J. Physiol. (Lond.), 220: 547-563.

Neto, F. R. and Sperelakis, N. (1989) Analysis of the hyperpolarizing effect of catecholamines on canine cardiac Purkinje fibers. Br. J. Pharmacol., 96: 591-598.

Palatini, P., Dabbeni-Sala, F., Pitotti, A., Bruni, A., and Mandersloot, J. C. (1977) Activation of $\left(\mathrm{Na}^{+}+\mathrm{K}^{+}\right)$-dependent ATPase by lipid vesicles of negative phospholipids. Biochim. Biophys. Acta, 466: 1-9.

Sheu, S. S., Korth, M., and Fozzard, H. A. (1981) Intracellular $\mathrm{K}^{+}$activity of cardiac Purkinje fibers during temperature change. In: Progress in Enzyme and Ion-Selective Electrodes, ed. by Lubbers, D. W., Acker, H., Buck, R. P., Eisenman, G., Kessler M., and Simon, W., Springer-Verlag, Berlin, pp. 183-188.

SkinNeR, R. B. and KUNZE, D. L. (1976) Changes in extracellular potassium activity in response to decreased $\mathrm{pH}$ in rabbit atrial muscle. Circ. Res., 39: 678-683. 
Sperelakis, N. and LeE, E. C. (1971) Characterization of $\left(\mathrm{Na}^{+}, \mathrm{K}^{+}\right)$-ATPase isolated from embryonic chick hearts and cultured chick heart cell. Biochim. Biophys. Acta, 233: 562-579.

Ten EICK, R. E. and Singer, D. H. (1979) Electrophysiological properties of diseased human atrium. Circ. Res., 44: 545-557.

Truex, R. C. (1972) Myocardial cell diameters in primate hearts. Am. J. Anat., 135: 269-280. 